\title{
Composition and Significance of Glycosaminoglycans in the Uterus and Placenta of Mammals
}

\author{
Gleidson Benevides de Oliveira ${ }^{1^{*}}$, André Menezes do Vale ${ }^{1}$, Amílton Cesar dos \\ Santos $^{2}$, Carlos Eduardo Bezerra de Moura ${ }^{1}$, Hugo Alexandre de Oliveira Rocha ${ }^{3}$ and \\ Moacir Franco de Oliveira ${ }^{1}$ \\ ${ }^{l}$ Departamento de Ciências Animais, Universidade Federal Rural do Semi-Árido; Mossoró - RN - Brasil. \\ ${ }^{2}$ Departamento de Cirurgia; Faculdade de Medicina Veterinária e Zootecnia; Universidade de São Paulo; São \\ Paulo - SP - Brasil. ${ }^{3}$ Departamento de Bioquímica; Universidade Federal do Rio Grande do Norte; Natal - RN - \\ Brasil
}

\begin{abstract}
Glycosaminoglycans (GAGs) are heteropolysaccharides in mammalian tissue and consist of repeated disaccharide units with mono-sulfated or non-sulfated monosaccharides. GAGs are important components of the Extracellular Matrix (ECM) with several physiological roles, in the recognition, migration, adhesion, proliferation and differentiation processes. They are also important in angiogenesis, blood homeostasis, immune reactions, follicule development and also in the development of pathologies such as infertility, tumors and metastases. It has been shown that the profile of glycosaminoglycans in the uterine and placental tissues is highly variable throughout the reproductive cycle and during pregnancy. It may be directly related to their physiological or pathological functions in the tissue. The latter has recently triggered special clinical interest. Current review collaborates for a deeper knowledge on the profile and importance of GAGs in uterine and placental tissues throughout the reproductive cycle and pregnancy. It also covers information on the involvement of these molecules in pathological processes.
\end{abstract}

Key words: Extracellular matrix, hormonal fluctuation, reproductive events, euterium mammals, pathology

\section{INTRODUCTION}

Until recently the main factor related to the onset of pathologies in mammals consisted of changes inherent to cells. The development of techniques in molecular biology brought about the analysis between cells and their environment: the extracellular matrix $(\mathrm{ECM})$ - the tridimensional structure that makes up complex macromolecules that participate actively in cell functions and are able to interact between themselves and the cells, while keeping them together to warrant tissue organization and cell survival (Kresse and Schönher 2001; Heinegard 2009). Such characteristics form the matrix's fundamental factors, mainly glycosaminoglycans (GAGs) and proteoglycans (PGs), as its principal elements up to its most varied metabolic processes.

Current review acknowledges the importance of GAGs in the uterine and placenta tissues throughout the reproduction cycle and pregnancy, coupled to information on the involvement of the molecules in pathological processes.

\section{EXTRACELLULAR MATRIX}

The Extracellular Matrix (ECM) is composed of a set of macromolecular aggregates comprised of

*Author for correspondence: gleidson_benevides@hotmail.com 
collagens, multi-adhesive glycoproteins, elastin, glycosaminoglycans (GAGs) and proteoglycans (PGs) (Kresse and Schönher 2001; Heinegard 2009). Further, ECM contains growth factors, cytocines or chemotactic factors, degradation enzymes and cryptic peptides that are exposed by the peptide activities (Schenk and Quaranta 2003; Korpos et al. 2010). ECM components interact between themselves and with cells. Interactions have an essential role in normal physiology and in many pathological events.

The ECM in rats' uterus is abundant during the estrum cycle and at the onset of pregnancy, but rare in decidualized areas. The endometrial extracellular matrix in humans has an important role in decidualization processes, implantation of the embryo, invasion of the trophoblast and in the maintenance of pregnancy (Iwhaashi et al. 1996).

\section{GLYCOSAMINOGLYCANS (GAGs)}

GAGs are heteropolysaccharides widely distributed in mammals' tissues and are formed by a basic structure of repetitive di-saccharide units with a hexosamine (glycosamine or galactosamine) linked to a non-nitrogenated sugar, uronic acid (D-glycuronic acid or L-iduronic acid) or a galactose. The polysaccharide chains are also called mucopolysaccharides due to the presence of viscose secretions. GAGs molecules are also present in all animal cells, with structural differences, depending on the original tissue or organism (Kjellen and Lindhal 1991).

Excepting the hyaluronic acid (HA), which is not sulfated and may be found freely in tissues, all the other GAGs are linked covalently to proteins and form proteoglycans (Berto et al. 2001). The proteins are linked to GAGs chains in the Golgi structure in stages that comprise several enzymes. PGs are immediately transported by secretory vesicles and directed by intracell granules to the cell surface or to the extracellular matrix (Nelson and Cox 2008).

The proteoglycans (PGs) are important components of the cell surface and of the ECM. They individually interact with other components of the matrix, such as collagen, laminine and fibronectine, and also with growth factors and cytocines. These interactions may affect cell growth, migration, adhesion and cell differentiation whose functions seem to be dependent on the GAGs' side chain (Merle et al.
1999; Schaefer and Schaefer 2010; Couchman and Pataki 2012).

The ability of proteins to link themselves to GAGs may be due to in vivo functional relationships. They include enzymes such as lipase lipoprotein, enzyme inhibitors (antithrombin), extracellular matrix proteins (fibronectine), growth factors, glycoprotein of viral lining, and others (Kjellén and Lindhal 1991).

Several authors have shown that glycosaminoglycans profile on the uterine tissue varies throughout the estrum cycle in animals and also in the menstrual cycle of primates. Since it differs throughout pregnancy and is directly related to its physiological functions in the tissue, it has recently been reported that it has a clinical role in medicine. The molecules act on cell recognition, migration, adhesion, proliferation and differentiation of the cells. In fact, it is directly or indirectly linked to the onset of tumors and metastases, in angiogenesis, in immunological reactions, in the development of follicles and in infertility (Dietrich 1984; Nasciutti et al. 2006; Li and Spillmann 2012; Malmström et al. 2012; Thelin et al. 2013). Due to their anionic features, GAGs are also involved in cation links (sodium, potassium and calcium, for instance) and in the retention of water in the tissues. They thus contribute towards the hydration of the extracellular matrix and in the molecular transport in the environment (Nelson and Cox 2008).

The main glycosaminoglycans in animals are chondroitin 4 sulfate, chondroitin 6 sulfate, dermatan sulfate (DS), heparan sulfate (HS), heparin (HE), keratan sulfate (QS) and hyaluronic acid (HA) which differ according to the type of hexosamine and non-aminated sugar, according to the degree and position of sulfatation and according to the type of glycoside bond (either $\alpha$ or $\beta$ ) (Fraser et al. 1997; Couchman and Pataki 2012). Kramer and Yost (2003); Lin (2004); Häcker et al. (2005) showed the importance of GAGs and PGs in several experimental models. Current article comprises a review on the profile and the role of glycosaminoglycans in the uterus and placenta of mammals, according to the different phases of the reproduction cycle and pregnancy.

\section{Uterus}

Chondroitin sulfate (CS), dermatan sulfate (DS), heparan sulfate (HS) and hyaluronic acid (HA) are the main GAGs in the extracellular matrix of the 
uterine tissue of mammals. Their concentrations may vary according to species, to the region in which the organ lies, to the reproduction cycle period and to the presence of certain affections in the tissue. It may be inferred that GAGs concentrations may be indicators of the reproduction cycle and the occurrence of certain uterine diseases (Table 1).

Table 1 - Glycosaminoglycans (GAGs) in the uterine tissue of euterium mammals and their relationship with the organ's physiology. $\mathrm{CS}=$ chondroitin sulfate, $\mathrm{DS}=$ dermatan sulfate, $\mathrm{HS}=$ heparan sulfate, HA=hyaluronic acid.

\begin{tabular}{|c|c|c|c|c|}
\hline Species & Tissue & GAGs & Physiology & Reference \\
\hline $\begin{array}{l}\text { Ovariectomized } \\
\text { female rats }\end{array}$ & $\begin{array}{l}\text { Uterine horns } \\
\text { and cervix }\end{array}$ & $\begin{array}{l}\text {-DS, HS and HA in both tissues; } \\
\text {-Use of estrogen associated to DS } \\
\text { increase; } \\
\text {-Treatment with progestagen: reduction } \\
\text { of HS in the horns and increase of HS in } \\
\text { the cervix; } \\
\text {-Use of estrogen + progesterone: } \\
\text { increase of sulfated GAGs. }\end{array}$ & -Modulated by sexual hormones; & $\begin{array}{l}\begin{array}{l}\text { Kofoed } \\
\text { et al. }\end{array} \\
(1972, \\
1977) ; \\
\text { Simões } \\
\text { et al. } \\
\text { (2012). }\end{array}$ \\
\hline Female rats & Uterine horns & $\begin{array}{l}\text { HA: increase when the implantation of } \\
\text { the embryo occurs. } \\
\text { Other GAGs remain constant during the } \\
\text { first five days of pregnancy. }\end{array}$ & $\begin{array}{l}\text { HA: biosynthesis followed by } \\
\text { decidual response in the } \\
\text { endometrium and may enhance } \\
\text { the implantation of the embryo. }\end{array}$ & $\begin{array}{l}\text { Carson } \\
\text { et al. } \\
(1987)\end{array}$ \\
\hline Female rats & Cervix & $\begin{array}{l}\text { - GAGs: DS, HS and HA; } \\
\text { - Greater amount of GAGs in the estrus } \\
\text { phase; } \\
\text { - DS predominant in estrus and HS in } \\
\text { the proestrus. }\end{array}$ & $\begin{array}{l}\text { Hormonal variation related to the } \\
\text { estrus may affect the uterine } \\
\text { cervix through the effect in the } \\
\text { production of sulfate heparan and } \\
\text { sulfate dermatan. }\end{array}$ & $\begin{array}{l}\text { Cubas } \\
\text { et al. } \\
(2010)\end{array}$ \\
\hline Female mices & $\begin{array}{c}\text { Cervix } \\
\text { (pregnancy) }\end{array}$ & $\begin{array}{l}\text { Relaxin (-/-) mice: lower Has } 2 \text { and } \\
\text { Aquaporin } 3 \text { expression on day } 18.5 \text { of } \\
\text { pregnancy and decreased cervical HA } \\
\text { compared with wild-type Relaxin (+/+). } \\
\text { Relaxin (-/-) mice treated with relaxin: } \\
\text { Chronic infusion of relaxin for } 4 \text { or } 6 \\
\text { days reversed these phenotypes and } \\
\text { increased Has } 2 \text { and Aquaporin3. }\end{array}$ & $\begin{array}{l}\text { Relaxin alters aquaporin } \\
\text { expression in the cervix and } \\
\text { initiates changes in GAGs } \\
\text { composition through increased } \\
\text { HA synthesis. These actions of } \\
\text { relaxin collectively promote water } \\
\text { recruitment into the extracellular } \\
\text { matrix to loosen the dense } \\
\text { collagen fiber network. }\end{array}$ & $\begin{array}{l}\text { Soh et al. } \\
\quad(2012)\end{array}$ \\
\hline $\begin{array}{l}\text { Female albino } \\
\text { rats }\end{array}$ & $\begin{array}{c}\text { Cervix } \\
\text { (pregnancy) }\end{array}$ & $\begin{array}{l}\text { Intracervical infusion of hyaluronidase: } \\
\text { a significant reduction of CS/DS and } \\
\text { HS. Reduction in HA staining in the } \\
\text { lamina propria and the area surrounding } \\
\text { the blood vessels. }\end{array}$ & $\begin{array}{l}\text { Intracervical hyaluronidase } \\
\text { infusion promoted a significant } \\
\text { reduction in the concentration of } \\
\text { sulfated GAGs. }\end{array}$ & $\begin{array}{l}\text { Souza } \\
\text { et al. } \\
(2014)\end{array}$ \\
\hline $\begin{array}{l}\text { Female rats and } \\
\text { women }\end{array}$ & $\begin{array}{l}\text { Cervix } \\
\text { (pregnancy at } \\
\text { term) }\end{array}$ & $\begin{array}{l}\text { HA: biosynthesis increase close to birth, } \\
\text { with peak on day of birth. }\end{array}$ & $\begin{array}{l}\text { Increase due to RNAm HAS2 } \\
\text { transcription close to birth, } \\
\text { suggesting HÁ regulation in the } \\
\text { cervix. }\end{array}$ & $\begin{array}{l}\text { Straach } \\
\text { et al. } \\
(2005)\end{array}$ \\
\hline \multirow{2}{*}{ Female rabbit } & Uterus & $\begin{array}{l}\text { Predominance of HS, followed by DS, } \\
\text { HA and CS. }\end{array}$ & $\begin{array}{l}\text { Difference in GAGs composition } \\
\text { between the uterine layers suggest } \\
\text { that the later have different roles } \\
\text { in reproduction. }\end{array}$ & $\begin{array}{l}\text { Endo and } \\
\text { Yosizawa } \\
(1975)\end{array}$ \\
\hline & $\begin{array}{l}\text { Myometrium } \\
\text { from } \\
\text { ovariectomized } \\
\text { females } \\
\end{array}$ & $\begin{array}{l}\text { CS: predominant followed by DS, HS } \\
\text { and HA and a small amount of } \\
\text { glycoprotein acids. }\end{array}$ & & $\begin{array}{l}\text { Endo et al. } \\
\text { (1978) }\end{array}$ \\
\hline Female rabbit & $\begin{array}{l}\text { Uterus treated } \\
\text { with estrogen }\end{array}$ & Main GAGs: CS, HS and DS & $\begin{array}{l}\text { Treatment with estrogen increases } \\
\text { the synthesis of sulfated GAGs in } \\
\text { the uterus, resulting from the } \\
\text { proliferation of the later due to } \\
\text { hormone activity. }\end{array}$ & $\begin{array}{l}\text { Munakata } \\
\text { et al. } \\
(1984)\end{array}$ \\
\hline Women & $\begin{array}{c}\text { Cervix } \\
\text { (pregnancy) }\end{array}$ & $\begin{array}{l}\text { Predominance of CS. } \\
\text { DS and HS in smaller amounts. } \\
\text { The collagen and sulfated gags were } \\
\text { elevated in tissue. }\end{array}$ & $\begin{array}{l}\text { During the menstrual cycle, GAGs } \\
\text { would be involved in the growth } \\
\text { and remodeling of the } \\
\text { endometrium. }\end{array}$ & $\begin{array}{l}\text { Nasciutti } \\
\text { et al. } \\
(2006) \\
\text { Myers et al. } \\
\text { (2008) } \\
\end{array}$ \\
\hline
\end{tabular}


Hormonal Influence in Gags Profile

GAGs in the uterus tissue are sensitive to hormonal variations that occur throughout the reproduction cycle. Variations may be linked to the physiological functions of these sugars (Kofoed et al. 1972; Kofoed et al. 1977; Simões et al. 2012).

The composition of glycosaminoglycan acids in rabbits' uterus has been reported in several research works (Endo and Yosizawa 1975; Endo et al. 1978; Endo et al. 1980). The molecules undergo concentration changes in the extracellular matrix of the endometrium and myometrium when androgens or progestogens are administered.

It has been reported that GAGs levels in the endometrium of ovarioectomized female rabbits, under exogenous application of estrogen, mainly consisted of HS, followed by DS, HA and CS, sulfated glycoprotein and sialoglycoprotein (Endo and Yosizawa 1975), whereas a higher concentration of CS occurred in the myometrium, followed by DS, HS, HA and sialoglycoprotein at lower concentrations (Endo et al. 1978). Another analysis revealed that the effect of estrogen on GAGs is suppressed in animals treated with estrogen, followed by progesterone. Molecule concentration in the uterine tissue is reduced, mainly the concentration of acid glycoproteins. It may be surmised that that synchronized control of the metabolism of these glycoproteins are relevant in reproduction (Endo et al. 1980).

An increase in sulfated GAGs in the uterus, especially the increase of CS and DS, occurs in female rats' estrogen phase, whereas in the progesterone phase there is a slight HS increase. The high concentration of GAGs during estrum foregrounds the uterus's macroscopic increase, since these molecules trigger tissue hydration and, at the same time, tissue hyperplasia (Cubas et al. 2010).

Studies on bitches during the anestrus phases or estrus and the comparison of GAGs rates in the fluids of the ampulla and isthmus of the uterine tubes and the lumen of the uterine horns showed that GAGs concentrations in these organs are greater in the bitches in the estrus when compared to those in the anestrus phase (Kawakami et al. 2000). This is due to estrogen on the genital organs during the estrus cycle.

Another investigation reports that alterations of prolactin's serum levels, similar to metoclopramide-induced hyperprolactinemia, triggers changes in endometrial GAGs composition and the decrease in serum levels of estrogen and progesterone during the estrus cycle in female rats. A thickness in the endometrium wall exists in hyperprolactinemia, followed by an increase in CS and DS synthesis in all the phases of the estrus cycle. It also causes the thickness of the uterus due to water retention (Gomes et al. 2013).

GAGs composition and levels are changed in pregnancy. They are of great importance in the uterine and placenta development, during birth and in the post-partum uterus involution, since their functions regulate the organization of the macromolecules of the extracellular matrix. Growth of the uterus and rigidity of the cervix occur at the onset of pregnancy. Later on, it becomes a flexible structure for the passage of the newly-born. At the end, GAGs levels are high when compared with the start of pregnancy and normally associated with HA increase (Golichowski et al. 1980; El Maradny et al. 1997). It has been reported that HA concentrations in pregnant rats' cervix were four-fold when compared to the start of pregnancy. This characteristic was co-related to the increase of the gene HAS2 transcription, positively affected by estrogen which, close to birth, is rather high. Increased HA synthesis and changes induced by hyaluronidase trigger alterations in the macromolecules of the extracellular matrix, with loss of traction resistance in birth (Akgul et al. 2012).

\section{Other Functional Aspects of Gags}

GAGs act directly on the fertilization and embryo implantation process in mammals. Studies on the fluid from the uterine tubes and lumen in mares in the pre-ovulation and post-ovulation phase showed that GAGs had a greater quantity in the pre- and post-ovulation phases and greater concentrations in the uterine lumen when compared to that in the uterine tube. Increase in GAGs concentration in the lumen of mares' reproduction tract during the follicular phase of the estrus cycle foregrounds the hypothesis that these molecules may have a basic role in events associated with the ovule's fertilization process (Varner et al. 1991).

GAGs and PGs are involved in the embryo implantation and in the decidualization process. Reports on female rats some days after copulation showed that versican (PG composed of CS/DS) and HA, prior to the embryo implantation, could be found in the endometrial stroma. When 
implantation occurs, the HA may be registered only in the peri-decidual region. At the same time, versican accumulates in the decidua area and indicates that the molecules participate in endometrial decidualization and/or in the implantation of the embryo (San Martin et al. 2003).

Research work with the reproduction tract of cows registered an increase in CS in the cervical mucus during estrus when compared to the cervical mucus during the di-estrus phase (Lee and Ax 1984). The latter suggests that the molecules act in the spermatic capacitation process. Motility and spermatozoid capacity in cattle are effectively induced by the addition of CS, HA or HP due to the fact that they trigger functional changes in the cellular membrane of the male gamete (Mahmoud and Parrish 1996), stimulate the absorption of calcium (McNutt et al. 1992) and the activation of intracellular cyclic AMP (Parrish et al. 1994).

GAGs are active in the process of the opening of the uterine cervix (Golichowski et al. 1980;El Maradny et al. 1997). Cervical ripening is associated with loss of structural integrity and tensile strength, thus enabling the cervix to dilate at term. It is characterized by changes in glycosaminoglycan composition, increased water content, and a progressive reorganization of the collagen network (Soh et al. 2012).

Research works in pregnant women showed that HA concentrations are low, especially at the moment of birth. It is the occasion when an increase in the activity of metaloproteinases occurs (enzymes causing the degradation of the components of the extracellular matrix and basal membranes) which participate effectively in the tissue remodellation process and in the postpartum uterine involution. Changes in HA levels also promote an increase in the migration of leucocytes and the activation of the opening process of the uterine cervix (El Maradny et al. 1997). In cases of infections, the opening mechanism of the uterine cervix occurs due to the influx of neutrophils into the cervix, a robust proinflammatory response and increased expression of prostaglandin-cyclooxygenaseendoperoxide synthase 2, important in prostaglandin biosynthesis (Holt et al. 2011).

Alterations in GAGs composition of the uterine cervix in sheep throughout pregnancy show preparations for birth-giving. Changes in the extracellular matrix of the cervix may be biochemically observed in the third initial phase of pregnancy. They are detected by an increase in DS synthesis. Approximately around the $100^{\text {th }}$ day, a decrease in the amount of collagen fibers occurs, followed by a decrease in PGs and HA levels, together with a water increase in the tissue. Since several collagen fibers are destroyed, a release of cytocines occurs which stimulate the invasion of inflammatory cells in the cervix. The latter causes the release of enzymes with collagenase and proteinase activity (Fosang et al. 1984; Akins et al. 2011). Endogenous enzymes alternatively may react to changes in the circulating hormones such as the decrease of post-partum progesterone. Endogenous enzymes may respond to changes in circulating hormones such as the reduction of prepartum progesterone and increase in estrogen, since these steroids have a stimulating activity to produce collagenase or an inhibitory activity to collagenolysis in vitro (Jeffrey et al. 1971) and in vivo (Halme and Woessner 1975).

\section{Placenta}

Several research works have shown that PGs, GAGs and adhesion proteins have a remarkable effect on cell behavior and affect tissue proliferation and differentiation. The literature reports on amorphous material, a dense electron that easily stains by Schiff Periodic Acid (SPA), in the placenta's maternal-fetal interface which varies throughout pregnancy and also among mammal species (Lovell et al. 1967; Calatroni and Di Ferrante 1969; Lee et al. 1973; Wasserman et al. 1983; Ott et al. 1997).

It may be surmised that changes in the placenta tissue during the maturation process, mainly in the molecular composition and structure of GAGs in the tissue may give rise to an extracellular matrix with different physical characteristics. Changes may alter molecule transport through the placenta's connective tissue and would affect directly the rate of fetal growth (Lee et al. 1973), which varies at different pregnancy phases.

The placenta contains two important types of PGs, or rather, PGs with the HS chain and PGs with CS and DS. The first type includes sindecan and perlecan (Jokimaa et al. 1998; Yang et al. 2005), whereas the second includes decorin and biglican (Chen et al. 2007). Several studies have shown that sindecan 1 is highly expressed in the syncytiotrophoblast region (Rajaraman 2009). Further, decorin lies in the stroma and surrounds the fetal blood vessels of the villous placenta (Swan et al. 2010). On the other hand, biglican lies 
in the endothelium and in the smooth muscular cells of the fetal capillaries (Murthi et al. 2010).

PGs and their GAGs side chains have an important anticoagulant activity to avert possible thrombotic events within the placenta. The HS chain bonds to the antithrombine activity by a sequence of pentasaccharides, whereas the DS chain bonds to heparin's co-factor II. GAGs undergo a change in their conformation and thus facilitate the inhibition of thrombin and avert the formation of thrombus in the placenta (Giri and Tollefsen 2006).

It seems that GAGs and in particular CS and HA in ruminants may be involved in the formation of placentomes, a structure which is characteristic to the placenta, whose number is limited by the amount of fetal caruncles (Lee et al. 1973; Greiss and Wagner 1983). At the onset of pregnancy, HA is the predominant GAG of the extracellular matrix of the placentomes, which seems to be restricted almost exclusively to the fetal villous mesenchyme. Concentrations of these GAGs increase throughout pregnancy and reach their lowest levels together with the structural maturing of the placentome and the acceleration of fetal growth. It is presumed that the mechanism that regulates HA levels during pregnancy determines the process of placenta maturation and fetal growth (Ott et al. 1997).

Researchers disagree with regard to the characterization of GAGs levels in the human placenta (Table 2). Some authors maintain that CS and HA on the placenta stroma are the main GAGs of the tissue, with a lower amount of DS and HS associated with fetal vessels and on the intervillous surface of the syncytiotrophoblast (Wasserman et al. 1983). Localization of these GAGs reveals that CS and HA have an important role in the maintenance of the structural integrity of the placenta by avoiding tissue compression due to its affinity to water (Lovell et al. 1967). At the same time, DS and HS would be involved in the process of blood homeostasis in sites where coagulation is risky (Wasserman et al. 1983; Said 2011; Chui et al. 2012).

Table 2 - Glycosaminoglycans (GAGs) in the placenta tissue of euterius mammals and their relationship with the organ's physiology. $\mathrm{CS}=$ chondroitin sulfate, $\mathrm{DS}=$ dermatan sulfate, HS=heparan sulfate, HA=hyaluronic acid.

\begin{tabular}{|c|c|c|c|c|}
\hline Species & Tissue & GAGs & Physiology & Reference \\
\hline Human & Placenta at term & $\begin{array}{l}\text {-Hyaluronic acid, Chondroitin } 6 \\
\text { sulfate, Chondroitin } 4 \text { sulfate. } \\
\text {-Small portion of DS and HS } \\
\text { between the maternal and fetal } \\
\text { interface. }\end{array}$ & $\begin{array}{l}\text { DS and HS form na electrochemical } \\
\text { barrier against the passage of } \\
\text { immunocompetent cells from the } \\
\text { mother to the fetus. }\end{array}$ & $\begin{array}{l}\text { Calatroni and } \\
\text { Di Ferrante } \\
\text { (1969). }\end{array}$ \\
\hline Human & $\begin{array}{l}\text { Young placenta } \\
\text { Placenta at term }\end{array}$ & $\begin{array}{l}\text {-Young placenta: CS and non- } \\
\text { sulfated chondroitin in great } \\
\text { amounts. } \\
\text {-Placenta at term: greater amounts } \\
\text { of sulfated GAGs, followed by DS } \\
\text { and HS increase. }\end{array}$ & $\begin{array}{l}\text { Changes at GAGs levels with the } \\
\text { maturation of the placenta would be } \\
\text { related to the role of these molecules in } \\
\text { the regulation of placenta transport. }\end{array}$ & $\begin{array}{l}\text { Lee et al. } \\
(1973)\end{array}$ \\
\hline Human & $\begin{array}{l}\text {-Placenta during } \\
\text { the first } 3 \text { months } \\
\text {-Placenta at term }\end{array}$ & $\begin{array}{l}\text {-Main GAGs: CS and HA in the } \\
\text { placenta stroma and DS and HS } \\
\text { associated with fetal blood vessels } \\
\text { and syncytial surface. }\end{array}$ & $\begin{array}{l}\text { Maintenance of structural integrity and } \\
\text { possibly in the blood homeostasis } \\
\text { process. }\end{array}$ & $\begin{array}{l}\text { Wasserman } \\
\text { et al. (1983) }\end{array}$ \\
\hline Human & $\begin{array}{l}\text { Placenta as from } \\
\text { pre-eclampsia }\end{array}$ & $\begin{array}{l}\text { Significant difference in GAGs } \\
\text { sulfatation pattern. }\end{array}$ & $\begin{array}{l}\text { Possible bond between pre-eclampsia } \\
\text { and changes in placental GAGs. }\end{array}$ & $\begin{array}{l}\text { Warda et al. } \\
\text { (2008) }\end{array}$ \\
\hline Human & $\begin{array}{l}\text { Placenta during } \\
\text { the last } 3 \text { months }\end{array}$ & $\begin{array}{l}\text { Fetal Growth Restriction (FGR): } \\
\text { biglycan mRNA and biglycan } \\
\text { protein expression was decreased in } \\
\text { FGR placentae compared with } \\
\text { control placentae. The biglycan was } \\
\text { detected in endothelial cells and } \\
\text { sub-endothelial cells of the } \\
\text { perivascular region of fetal } \\
\text { capillaries. }\end{array}$ & $\begin{array}{l}\text { Reduced biglycan expression may } \\
\text { contribute to placental thrombosis } \\
\text { within the fetal vasculature, and may } \\
\text { contribute to the pathogenesis of } \\
\text { idiopathic FGR. }\end{array}$ & $\begin{array}{l}\text { Murthi et al. } \\
\text { (2010) }\end{array}$ \\
\hline Ovine & Placentoma & $\begin{array}{l}\text { Hyaluronic acid predominant in the } \\
\text { initial phases and in mid pregnancy. }\end{array}$ & $\begin{array}{l}\text { Regulating mechanism of hyaluronic } \\
\text { acid which is determinant in the } \\
\text { process of placental maturation and in } \\
\text { fetal growth }\end{array}$ & $\begin{array}{c}\text { Ott } \\
\text { et al.(1997) }\end{array}$ \\
\hline
\end{tabular}


Human immature and at term placenta comprises HA, CS, non-sulfated chondroitin, DS, HS at different proportions and low QS levels. A higher amount of sulfated GAGs in the placenta at term has been reported when compared to the placenta at the initial phase (Lee et al. 1973). Other studies register HA, chondroitin 6 sulfate and DS in the chorionic vilosity region, but do not report changes in the concentrations of the later throughout pregnancy (Lovell et al. 1967).

Studies on the placenta at term (Calatroni and Di Ferrante 1969) demonstrate that HA, chondroitin 6 sulfate, chondroitin 4 sulfate and a small amount of DS and HS are the polysaccharides that comprise the placenta's extracellular matrix. The latter two trigger the formation of electro-chemical barriers: the former lies on the mesenchyme tissue between the maternal and fetal vascular structures, whereas the latter lie on the maternal and fetal sinusoid capillaries. This hyaluronidase-resistant double barrier guarantees a lasting and effective protection against the migration of immunocompetent cells from the mother to the offspring (Calatroni and Di Ferrante 1969).

\section{CONCLUSION}

The extracellular matrix which for a long time has been thought to be an inert complex of macromolecules has been the focus of several researchers who began understanding the role of glycosaminoglycans and proteoglycans in the reproduction tissues.

GAGs involvement in physiological processes has revealed that the molecules lie in the uterus and the placenta throughout the estrus and menstrual cycle and during pregnancy, with variable profiles among several animal species.

Knowledge on the structure and composition of GAGs may be relevant for studies since they may be used as biomarkers and thus employed in the diagnosis and prognosis of pathologies of the female reproduction tract and in the choice of therapies.

\section{REFERENCES}

Akgul Y, Holt R, Mummert M, Word A, Mahendroo M. Dynamic Changes in Cervical Glycosaminoglycan Composition during Normal Pregnancy and Preterm Birth. Endocrinology. 2012; 153(7): 3493-3503.
Akins ML, Luby-Phelps K, Bank RA, Mahendroo M. Cervical softening during pregnancy-regulated changes in collagen cross-linking and composition of matricellular proteins in the mouse. Biol Reprod. 2011; 84: 1053-1062.

Anand M, Wang C, French J, Isaacson-Schmid M, Wall LL, Mysorekar IU. Estrogen Affects the Glycosaminoglycan Layer of the Murine Bladder. Female Pelvic Med Reconstr Surg. 2012; 18(3): 148152.

Berardo PT, Abrao MS, Souza ML, Machado DE, Silva LC, Nasciutti LE. Composition of sulfated glycosaminoglycans and immunodistribution of chondroitin sulfate in deeply infiltrating endometriosis affecting the rectosigmoid. Micron. 2009; 40(5-6): 639-645.

Berto AGA, Oba SM, Michelacci YM, Sampaio LO. Galactosamynoglycans from normal miometrium and leiomyoma. Braz J Med Biol Res. 2001; 34: 633-637.

Calatroni A, Di Ferrante N. The Glycosaminoglycans of human term placenta. Carbohyd Res. 1969; 10(4): 535-548.

Carson DD, Dutt A, Tang JP. Glycoconjugate Synthesis during early pregnancy: hyaluronate synthesis and function. Dev Biol. 1987; 120(1): 228-235.

Couchman JR, Pataki CA. An introduction to proteoglycans and their localization. J. Histochem. Cytochem. 2012; 60(12): 885-897.

Chen CP, Chang SC, Yang WCV. High glucose alters proteoglycan expression and the glycosaminoglycan composition in placentas of women with gestacional diabetes mellitus and in cultured trophoblasts. Placenta. 2007; 28(2-3): 97-106.

Chui A, Zainuddin N, Rajaraman G, Murthi $\mathrm{P}$, Brennecke SP, Ignjatovic $\mathrm{V}$, et al. Placental syndecan expression is altered in human idiopathic fetal growth restriction. Am J Pathol. 2012; 180(2): 693-702.

Cubas JJM, Simões RS, Oliveira-Filho RM, Simões MJ, Baracat EC, Soares-Jr JM. Glycosaminoglycan Distribution in the Rat Uterine Cervix During the Estrous Cycle. Clinics (Sao Paulo). 2010; 65(7): 703 708.

Dietrich CP. A model for cell-cell recognition and control of cell growth mediated by sulfated glycosaminoglycans. Braz J Med Biol Res. 1984; 17(1): 5-15.

El Maradny E, Kanayama N, Kobayashi H, Hossain B, Khatun S, Liping S, et al. The role of hyaluronic acid as a mediator and regulator of cervical ripening. Hum Reprod. 1997; 12(5): 1080-1088.

Endo M, Yosizawa Z. Glycosaminoglycans and acidic glycoproteins in rabbit uterus under estrogenic conditions. Biochim Biophys Acta. 1975; 404(2): 274-280. 
Endo M, Shimizu T, Munakata H, Yosizawa Z. Composition of Acidic Glycoconjugates (Glycosaminoglycans and Glycoprotein) in myometrium of rabbit uterus under estrogenic condition. Tohoku J Exp Med. 1978; 126(2): 103-110.

Endo M, Yosizawa, Z. Progesterone Effect on the Biosynthesis of Glycoconjugates, Specifically of Sulfated Glycoprotein, in the Endometrium of Rabbit Uterus. Tohoku J Exp Med. 1980; 132(2): 147-152.

Fosang AJ, Handley CJ, Santer V, Lowther DA, Thorburn GD. Pregancy-Related Changes in the Connective Tissue of the Ovine Cervix. Biol Reprod. 1984; 30(5): 1223-1235.

Fraser JRE, Laurent TC, Laurent UBG. Hyaluronan: its nature, distribution, functions and turnover. J Intern Med. 1997; 242(1): 27-33.

Giri TK, Tollefsen DM. Placental dermatan sulfate: isolation, anticoagulant activity, and association with heparin cofactor II. Blood. 2006; 107(7): 2753-2758.

Golichowski AM, King SR, Mascaro K. Pregnancyrelated changes in rat cervical glycosaminoglycans. Biochem Journal. 1980; 192(1): 1-8.

Greiss FC, Wagner WD. Glycosaminoglycans: Their distribution and potential vasoactive action in the nonpregnant and pregnant ovine uterus. Am J Obstet Gynecol. 1983; 145(8): 1041-1048.

Gomes RCT, Maioral GCCC, Verna C, Patriarca MT, Nader HB, Simões RS, et al. Hyperprolactinemia changes the sulfated glycosaminoglycan amount on the murine uterus during the estrous cycle. Fertil Steril. 2013; 100(5): 1419-1427.

Häcker U, Nybakken K, Perrimon N. Heparan sulphate proteoglycans: the sweet side of development. Nat Rev Mol Cell Biol. 2005; 6(7): 530-541.

Halme J, Woessner JF. Effect of progesterone on collagen breakdown and tissue collagenolytic activity in the involuting rat uterus. J Endocrinol. 1975; 66(3): 357-362.

Holt R, Timmons BC, Akgul Y, Akins ML, Mahendroo M. The molecular mechanisms of cervical ripening differ between term and preterm birth. Endocrinology. 2011; 152(3): 1036-1046.

Itano N, Sawai T, Atsumi F, Miyaishi O, Taniguchi $\mathrm{S}$, Kannagi R, et al. Selective expression and functional characteristics of three mammalian hyaluronan synthases in oncogenic malignant transformation. Journal Biol. Chem. 2004; 279(18): 18679-18687.

Iwahashi M, Muragaki Y, Ooshima A, Yamoto M, Nakano R. Alterations in distribution and composition of the extracellular matrix during decidualization of the human endometrium. J Reprod Fertil. 1996; 108(1): 147-155.
Jeffrey JJ, Coffey RJ, Eisen, AZ. Studies on uterine collagenase in tissues culture II. Effect of steroids hormones on enzyme production. Biochim Biophys Acta. 1971; 252(1): 143-149.

Jokimaa V, Inki P, Kujari H, Hirvonen O, Ekholm E, Anttila L. Expression of syndecan-1 in human placenta and decidua. Placenta. 1998; 19(2-3): 157163.

Kawakami E, Arai T, Oishi I, Hori T, Tsutsui T. Induction of Dog Sperm Capacitation by Glycosaminoglycans and Glycosaminoglycan Amounts of Oviductal and Uterine Fluids in Bitches. $J$ Vet Med Sci. 2000; 62(1): 65-68.

Kjellén L, Lindahl U. Proteoglycans: Strudures and Interactions. Annu Rev Biochem. 1991; 60: 443-475.

Kofoed JA, Houssay AB, Tocci AA, Curbelo HM. Effects of oestrogens upon glycosaminoglycans in uterus of rats. Acta Endocrinol (Copenh). 1972; 69(1): 87-94.

Kofoed JA, Houssay AB, Tocci AA, Curbelo HM, Barcelo C. Effects of acetoyprogesterone upon glycosaminoglycans in uterus and salivary glands of rats. Horm Metab Res. 1977; 9(1): 58-59.

Korpos E, Wu C, Song J, Hallmann R, Sorokin L. Role of the extracellular matrix in lymphocyte migration. Cell Tissue Res. 2010; 339(1): 47-57.

Kramer KL, Yost HJ. Heparan sulphate core proteins in cell-cell signaling. Annu Rev Genet. 2003; 37: 461484.

Kresse H, Schönher E. Proteoglycans of the extracellular matrix and growth control. J Cell Physiol. 2001; 189(3): 266-274.

Lee CN, Ax RL. Concentrations and composition of glycosaminoglycans in the female bovine reproductive tract. J Dairy Sci. 1984; 67(9): 20062009.

Lee TY, Jamieson AM, Schafer IA. Changes in the composition and structure of glycosaminoglycans in the human placenta during development. Pediatr Res. 1973; 7(12): 965-977.

Li JP, Spillmann D. Heparan sulfate proteoglycans as multifunctional cell regulators: cell surface receptors. Methods Mol Biol. 2012; 836: 239-255.

Lin X. Functions of heparan sulfate proteoglycans in cell signaling during development. Development. 2004; 131(24): 6009-6021.

Lovell D, Tighe JR, Curran RC. The chemical determination of acido mucopolysaccharides and collagen of the normal human placenta. J Obstet Gynaecol Br Commonw. 1967; 74(4): 568-571.

Mahmoud AI, Parrish JJ. Oviductal fluid and heparin induce similar surface changes in bovine sperm during capacitation: a flow cytometric study using lectins. Mol Reprod Dev. 1996; 43(4): 554-560. 
Malmström A, Bartolini B, Thelin MA, Pacheco B, Maccarana M. Iduronic acid in chondroitin/dermatan sulfate: biosynthesis and biological function. J Histochem Cytochem. 2012; 60(12): 916-925.

McNutt T, Rogowski L, Vasilatos-Younken R, Killian G. Adsorption of oviductal fluid proteins by the bovine sperm membrane during in vitro capacitation. Mol Reprod Dev. 1992; 33(3): 313-323.

Merle B, Durussel L, Delmas PD, Clézardin P. Decorin inhibits cell migration through a process requiring its glycosaminoglycan side chain. J Cell Biochem. 1999; 75(3): 538-546.

Munakata $\mathrm{H}$, Isemura $\mathrm{M}$, Yosizawa Z. Sulfated glycosaminoglycans synthesized in rabbit uterus. Tohoku J Exp Med. 1984; 143(2): 205-212.

Murthi P, Faisal FA, Rajaraman G, Stevenson J, Ignjatovic V, Monagle PT, et al. Placenta biglycan expression is decreased in human idiopathic fetal growth restriction. Placenta. 2010; 31(8): 712-717.

Myers KM, Paskaleva AP, House M, Socrate S. Mechanical and biochemical properties of human cervical tissue. Acta Biomater. 2008; 4(1):104-116.

Nasciutti LE, Ferrari R, Berardo PT, Souza ML, Takiya CM, Borojevic R. Distribuition of condroitin sulfate in human endometrium. Micron. 2006; 37(6): 544550 .

Nelson DL, Cox MM. Lehninger Principles of Biochemistry. 5th ed. New York: WHA Freeman and Company; 2008.

Ott TL, Wiley AA, Bartol FF. Effects of Stage of Gestation and Uterine Ligation on Ovine Placentome Development and Glycosaminoglycans. J Anim Sci. 1997; 75(4): 1053-1062.

Parrish JJ, Susko-Parrish JL, Uguz C, First NL. Differences in the role of cyclic adenosine 3,5monophosphate during capacitation of bovine sperm by heparin or oviduct fluid. Biol Reprod. 1994; 51(6): 1099-1108.

Rajaraman G. Placental syndecan-1 expression is significantly reduced in idiopathic fetal growth restriction. Placenta. 2009; 30(9): 72.

Schaefer L, Schaefer RM. Proteoglycans: from structural compounds to signaling molecules. Cell and Tissue Research. 2010; 339(1): 237-246.

Schenk S, Quaranta V. Tales from crypt[ic] sites of the extracellular matrix. Trends Cell Biol. 2003; 13(7): 366-375.

Said JM. The role of proteoglycans in contribuiting to placental thrombosis and fetal growth restriction. $J$ Pregnancy. 2011; 2011: 928381.
San Martin S, Soto-Suazo M, Zorn TMT. Distribution of versican and hyaluronan in the mouse uterus during decidualization. Braz J Med Biol Res. 2003; 36(8): 1067-1071.

Simões RS, Oliveira-Filho RM, Nader HB, Baracat EC. Glycosaminoglycan profiles in the uterus of adult ovariectomized rats treated with estrogen and progestagen. Eur J Obstet Gynecol Reprod Biol. 2012; 165(2): 265-270.

Soh YM, Tiwari A, Mahendroo M, Conrad KP, Parry LJ. Relaxin regulates hyaluronan synthesis and aquaporins in the cervix of late pregnant mice. Endocrinology. 2012; 153(12): 6054-6064.

Souza GN, Camano L, Araujo Júnior E, Nader HB, Medeiros V, Martins JR, et al. The expression of glycosaminoglycans and proteoglycans in the uterine cervix of albino rats after local hyaluronidase infusion. J Matern Fetal Neonatal Med. 2014; 27(9): 879-886.

Straach KJ, Shelton JM, Richardson JA, Hascall VC, Mahendroo MS. Regulation of hyaluronan expression during cervical ripening. Glycobiology. 2005; 15(1): 55-65.

Swan BC, Murthi P, Rajaraman G, Pathirage NA, Said $\mathrm{JM}$, Ignjatovic $\mathrm{V}$, et al. Decorin expression is decreased in human idiopathic fetal growth restriction. Reprod Fertil Dev. 2010; 22(6): 949-955.

Thelin MA, Bartolini B, Axelsson J, Gustafsson R, Tykesson E, Pera E, et al. Biological functions of iduronic acid in chondroitin/dermatan sulfate. FEBS J. 2013; 280(10): 2431-2446.

Varner DD, Forrest DW, Fuentes F, Taylor TS, Hooper $\mathrm{RN}$, Brinsko SP, et al. Measurements of glycosaminoglycans in follicular, oviductal and uterine fluids of mares. J Reprod Fertil Suppl. 1991; 44: 297-306.

Warda M, Zhang F, Radwan M, Zhang Z, Kim N, Kim $\mathrm{YN}$, et al. Is human placenta proteoglycan remodeling involved in pre-eclampsia? Glycoconj $J$. 2008; 25(5): 441-450.

Wasserman L, Abramovici A, Shlesinger H, Goldman JA, Allalouf D. Histochemical Localization of Acidic Glycosaminoglycans in Normal Human Placentae. Placenta. 1983; 4(1): 101-108.

Yang WCV, Su TH, Yang YC, Chang SC, Chen $\mathrm{CY}$, Chen CP. Altered perlecan expression in placental development and gestacional diabetes mellitus. Placenta. 2005; 26(10): 780-788. 